ZOOLOGIA 30 (3): 324-328, June, 2013

http://dx.doi.org/10.1590/S1984-46702013000300010

\title{
Two new species of the spider genus Alpaida (Araneae: Araneidae) from restinga areas in Brazil
}

\author{
Gracielle F. Braga-Pereira' \& Adalberto J. Santos ${ }^{1}$
}

\begin{abstract}
${ }^{1}$ Departamento de Zoologia, Instituto de Ciências Biológicas, Universidade Federal de Minas Gerais. Avenida Antônio Carlos 6627, 31270-901 Belo Horizonte, MG, Brazil. E-mail: gracifbp@yahoo.com.br, oxyopes@yahoo.com
\end{abstract}

\begin{abstract}
Two new species of Alpaida O.P.-Cambridge, 1889 are described based on male and female specimens from seven restinga areas from northeastern to southern Brazil. Alpaida teresinha sp. nov., from Rio de Janeiro and Espírito Santo, differs from other species of the genus in the wider lobe of the conductor, the concave median apophysis and with the posterior lobe ventrally positioned, and the wrinkled distal projection of the terminal apophysis in males. Females can be recognized by having widely spaced epigynal lips and by the narrow epigynal notch in ventral view. Alpaida toninho sp. nov., from Bahia, Espírito Santo, Rio de Janeiro and Santa Catarina, can be distinguished by the round lobes of the terminal apophysis, and by the median apophysis with a distal lobe and a projection in males, and by the epigynum elliptical, with a short scape in females.
\end{abstract}

KEY WORDS. Brazilian coast; Neotropical Region; taxonomy.

Alpaida O.P.-Cambridge, 1889 is composed of 140 species (Platnick 2012) of diurnal orb web spiders. Known only from the New World, and one of the largest genera of Araneidae, this genus is estimated to contain 200-300 species (Levi 1988). Species of the genus are characterized by having orange to red carapace, carapace and abdomen without bristles, and females with the contours of the eyes darkened; the male palp has the paramedian apophysis mushroom-shaped and connected to the conductor and radix, and the embolus and terminal apophysis fused in a single structure; the sclerotized epigynum usually has a scape in the middle portion and posterior lips (Levi 1988).

Most of the species of the genus were described by LeVI (1988), who increased the number of described species of Alpaida from 40 to 134 . Two other species were later transferred to the genus, Alpaida tullgreni (Caporiacco, 1955), first described in Parawixia F.O.P.-Cambridge, 1904 (Levi 1992, redescribed in Levi 1993); and A. oliverioi (Soares \& Camargo, 1948), originally described in Cyclosa Menge, 1866 (Levi 1999, not redescribed due to the loss of palps of the holotype).

Some species of Alpaida have been described after Levi's (1988) revision, including a species from the Brazilian Amazon - Alpaida guto Abrahim \& Bonaldo, 2008 -, and three species from the Brazilian Atlantic Forest: A. itacolomi Santos \& Santos, 2010, A. tonze Santos \& Santos, 2010, and A. caramba Buckup \& Rodrigues, 2011. Another species, Alpaida arvoredo Buckup \& Rodrigues, 2011, was described based on the male specimens attributed by Levi (1988) to Alpaida hoffmanni Levi, 1988. In fact, most species of the genus remained known only from males or females, or have questionable male-female associations. In the past few years, the males of six species have been described:
Alpaida scriba (Melo-Leitão, 1940) by Buckup \& Meyer (1993), A. kochalkai Levi, 1988; A. lomba Levi, 1988 and A. hoffmanni by Buckup \& Rodrigues (2011), and A citrina (Keyserling, 1893) and A. octolobata (Levi, 1988) by Rodrigues \& MendonçA (2011). The only additional modification in the systematics of the genus was the synonymy of Alpaida roemeri (Strand, 1908) with Araneus naviculus L. Koch, 1871, proposed by Framenau et al. (2009).

The taxonomic history of Alpaida shows that, although it is amongst the best known Neotropical spider genera, much of its diversity is still to be described. At least part of this diversity can be found in ecosystems that have not received much attention from taxonomists, for instance the Brazilian restingas. Restingas are a set of Brazilian coastal plant communities present on sandy soils. Even though most plant species in it also occur in adjacent biomes, for instance the caatinga, at least some plant species are endemic to the restinga (CERQUeIrA 2000). The description of the restinga flora and fauna is particularly important, given that this information can be useful to guide conservation decisions. In this study, two new species of Alpaida are described based on specimens collected in an extensive study of restinga spider communities in several localities along the Brazilian coast (Thiago Gonçalves-Souza et al., unpubl. data).

\section{MATERIAL AND METHODS}

The specimens examined for this study were collected in six localities of the Brazilian coast, and are all deposited in the Coleções Taxonômicas da Universidade Federal de Minas Gerais (UFMG, curator A.J. Santos), Belo Horizonte. Specimens were 
examined and illustrated with an Olympus SZ40 stereoscopic microscope. The male and female genitalia were excised, airdried, fixed in aluminum rivets with adhesive copper tape and sputter-coated with $10 \mathrm{~nm}$ of gold. This material was examined under high vacuum in a Quanta 2000 Scanning Electron Microscope at the Centro de Microscopia da UFMG. Morphological terminology and description format were the same used by Levi (1988). All the measurements are in millimeters. Geographic coordinates of localities mentioned in the text are presented in decimal format, first latitude than longitude.

\section{TAXONOMY}

\section{Alpaida teresinha sp. nov.}

Figs 1-2, 5-7, 17

Types. Holotype male and paratype female from Restinga de Setiba (-20.607778, -40.424167), Guarapari, Espírito Santo, Brazil, T. Gonçalves-Souza leg., 28.IX-4.X.2009, deposited in UFMG 11109 and UFMG 11108 respectively.

Diagnosis. Males of Alpaida teresinha sp. nov. resemble those of A. lanei Levi, 1988 in the rectangular median apophysis with a lobe directed toward the cymbium and the squarish terminal apophysis of the palp (Levi 1988: fig. 171). The wider lobe of the conductor, the concave median apophysis with the posterior lobe positioned ventrally and the wrinkled distal projection of the terminal apophysis of $A$. teresinha sp. nov. (Fig. 5 ) distinguish this species from $A$. lanei. The female of $A$. teresinha is similar to that of $A$. marta Levi, 1988 in the shape of the epigynum, triangular in ventral view (Levi 1988: fig. 623), and to A. hoffmanni in the presence of two dorsal, round, dark spots on the posterior view of the epigynum (Levi 1988: fig. 93). They can be distinguished by the base of epigynal lips visible in posterior view (in A. marta it is hidden under the scape - Levi 1988: fig. 624) and by the narrow epigynal notch in ventral view (wide in A. hoffmanni) (Figs 6 and 7).

Description Male Holotype. Carapace orange, eye region yellow. Chelicerae, clypeus, sternum, coxae and trochanters I and II yellow. Trochanters III and IV, and remaining leg articles grayish-yellow. Endites yellow, with the central region gray. Labium yellow, with the upper half gray. Dorsum of abdomen yellow, with black spots on edges and center of distal portion (Fig. 1). Venter yellow, with few small, median black spots. Spinnerets black. Total length 3.35. Carapace 1.8 long, 1.47 wide. First femur 1.63 long, patella, tibia, metatarsus and tarsus lost. Second patella and tibia 1.47; third 0.95; fourth 1.36. Tegulum with ventral bump. Median apophysis with proximal projection and curved edge, forming a concave structure. Conductor with ventral hyaline lobe and ventral sclerotized one. Embolus relatively short, filiform. Terminal apophysis large and smooth, with distal, rough lobe (Fig. 5).

Female Paratype. Carapace orange-yellow, with median arrow-shaped, lighter stain bounded by dark lines. Venter pale yellow, with two marginal, longitudinal black lines. Chelicerae yellow, paler distally. Labium yellow, with two marginal darker. Endites, clypeus, sternum and coxae yellow. Legs yellow, with black rings at articulations. Dorsum of abdomen pale yellow, with median and lateral black spots (Fig. 2). Spinnerets black, surrounded by four white spots. Total length 3.55. Carapace 1.67 long, 1.37 wide. First femur 1.42 long, patella and tibia 1.62; metatarsus 1.01; tarsus 0.61 . Second patella and tibia 1.47; third 1.17; fourth 1.42. Epigynum paler anteriorly, with spermathecae visible through the transparent integument (Fig. 6). Posterior plate elliptical and hyaline, with spermathecae visible by transparency (Fig. 7).

Other material examined. BraziL, Rio de Janeiro: Maricá, Restinga de Maricá (-22.9605561, -42.842222), 6-8.VII.2010, 1 female (UFMG 7163); Espírito Santo: Guarapari, Restinga de Setiba (-20.607778, -40.424167), 28.IX-4.X.2009, 1 male and 2 females (UFMG 7186), all collected by T. Gonçalves-Souza.

Variation. Males $(\mathrm{N}=2)$ : carapace length, 1.65-1.8; females $(\mathrm{N}=4)$ : carapace length, $1.5-1.67$. Longitudinal dark lines present on legs of some specimens and arrow-shaped spot of female's carapace variable in size.

Natural History. All the specimens were collected in shrubby vegetation in areas of restinga. Specimens were found on plants of two families, Arecaceae (Allagoptera sp.) and Myrtaceae.

Distribution. Known from restinga areas of southeastern Brazil, in the states of Espírito Santo and Rio de Janeiro (Fig. 17).

Etymology. The specific epithet is a noun in honor on the senior author's mother, Teresinha das Graças Braga Pereira.

\section{Alpaida toninho sp. nov.}

Figs 3-4, 8-16, 17

Types. Holotype male from Restinga de Maricá (22.9605561, -42.842222), Maricá, Rio de Janeiro, Brazil, T. Gonçalves-Souza leg., 6-8.VII.2010, deposited in UFMG 11110. Paratype: female from Barra Nova (-18.958889, -39.740000), São Mateus, Espírito Santo, Brazil, T. Gonçalves-Souza leg., 2628.VII.2010, deposited in UFMG 11111.

Diagnosis. Males of Alpaida toninho sp. nov. resemble $A$. bicornuta (Taczanowski, 1878) in the presence of two sclerotized lobes on the terminal apophysis (see Levi 1988: fig. 18), but can be distinguished by the round lobes of the terminal apophysis (triangular in A. bicornuta) and the median apophysis with a distal lobe and a projection forming a cavity directed toward the cymbium (Figs 8 and 11-13). The epigynum differs from those of other species of Alpaida by being elliptical in ventral view, in the short scape and in the large notch (Figs 9 and 15). In posterior view it is similar to that of $A$. sumare Levi, 1988 in the round margin and in the presence of two little dark marks (Levi 1988: fig. 247) and can be distinguished by the longer proximal edge of the lip and the shorter scape (Figs 10 and 14).

Description. Male Holotype. Carapace orange-yellow, sternum yellow, clypeus white. Chelicerae yellow, white distally. Endites yellow with dark spots. Labium and coxae grayish-yellow. Legs yellow, with dark lateral longitudinal lines. Dorsum 

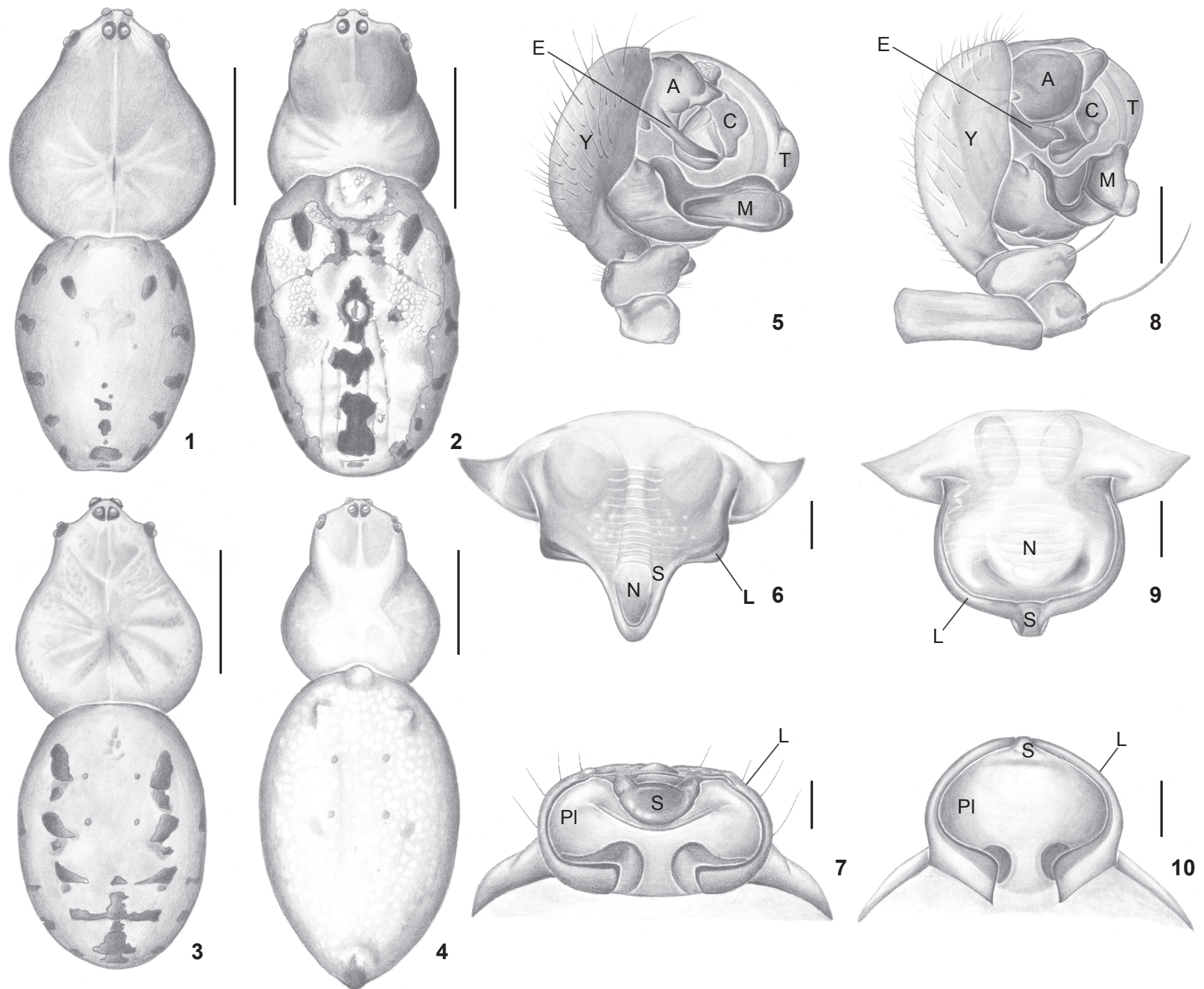

Figures 1-10. (1-2) Alpaida teresinha sp. nov., habitus, dorsal view: (1) male (holotype); (2) female (paratype). (3-4) Alpaida toninho sp. nov., habitus, dorsal view: (3) male (holotype); (4) female (paratype). (5-7) Alpaida teresinha sp. nov.: (5) male holotype, palp, ventral view; (6) female paratype, epigynum, ventral view; (7) ditto, posterior view. (8-10) Alpaida toninho sp. nov.: (8) male holotype, palp, ventral view; (9) female paratype, epigynum, ventral view; (10) ditto, posterior view.(A) Terminal apophysis, (C) conductor, (E) embolus, (L) epigynal lip, (M) median apophysis, $(\mathrm{N})$ epigynal notch, $(\mathrm{Pl})$ posterior median plate, $(\mathrm{S})$ scape, $(\mathrm{T})$ tegulum, $(\mathrm{Y})$ cymbium. Scale bars: $0.1 \mathrm{~mm}$.

of abdomen yellow, with two lateral and a median, anterior row of dark spots (Fig. 3). Venter with median dark spot and lateral dark lines. Spinnerets black. Distal part of abdomen with longitudinal black band. Total length 3.9. Carapace 1.63 long, 1.38 wide. First femur 1.5 long, patella and tibia 1.77; metatarsus 1.09; tarsus 0.61. Second patella and tibia 1.43; third 0.95; fourth 1.36. Tegulum convex, with round edge. Median apophysis sclerotized, with ventral projection. Conductor with rounded ventral edge. Embolus short and wide. Terminal apophysis with two plates (Figs 8 and 11-13). Paramedian apophysis curved anteriorly, mushroom-shaped apically (Fig. 13).
Female Paratype. Carapace orange-yellow, paler medially. Chelicerae yellow, paler distally. Clypeus, endites, sternum and coxae I and IV yellow. Labium and coxae II and III with dark spots. Legs yellow-orange, with dark rings at articulations. Sternum orange-yellow. Abdomen elongated, yellow, with dorsal white spots, tapering posteriorly, with terminal black spot. Anterior margin with a median and a pair of lateral small elevations (Fig. 4). Venter with median black spot and lateral black lines. Spinnerets black, near a black, longitudinal line on distal portion of abdomen. Total length 4.91. Carapace 1.77 long, 1.43 wide. First femur 1.16 long, patella and tibia 1.5; 

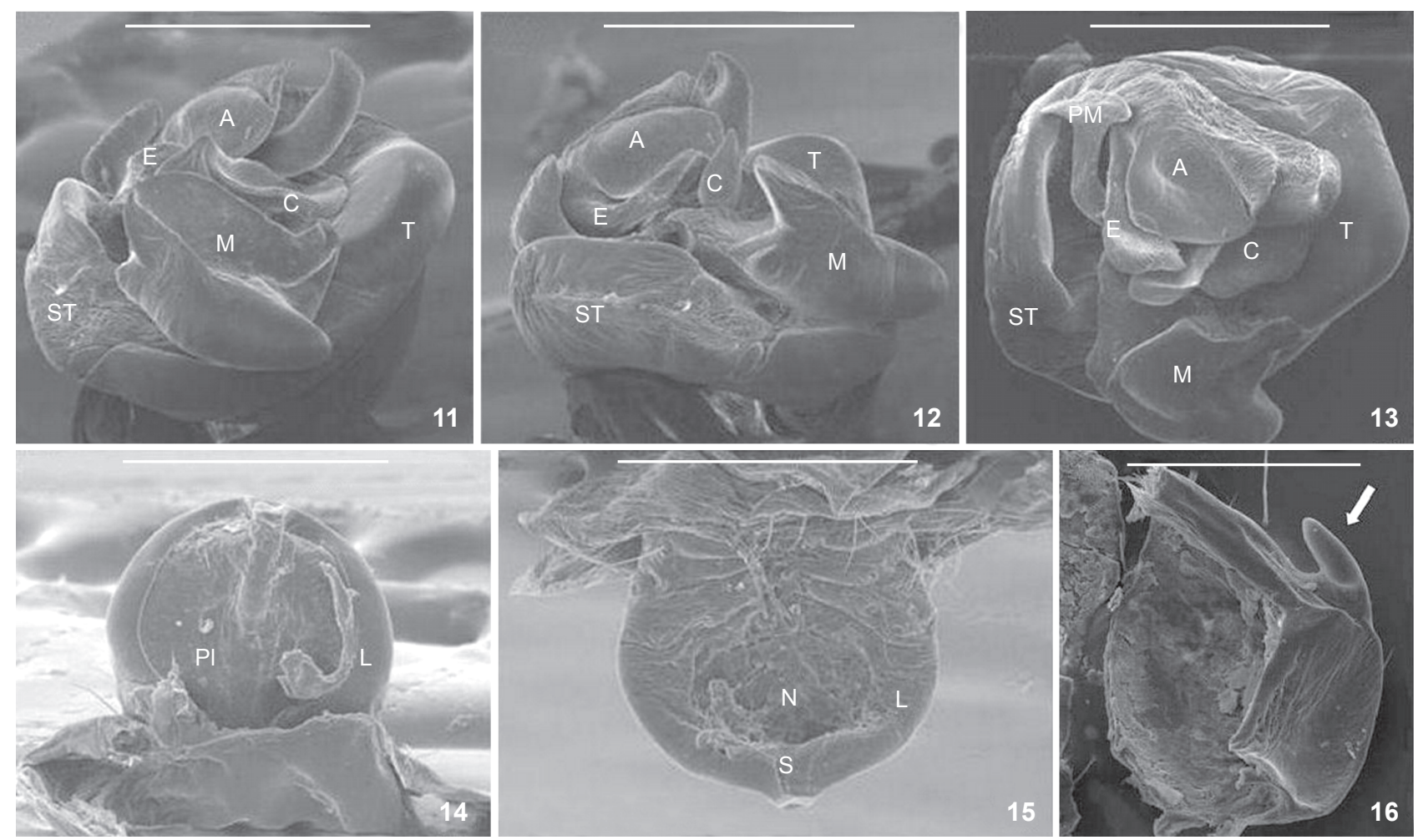

Figures 11-16. Alpaida toninho sp. nov. (11-13) male palp: (11-12) lateral view; (13) ventral view. (14-15) epigynum: (14) posterior view; (15) ventral view. (16): cymbium, ventral view (arrow points to the paracymbium). (A) Terminal apophysis, (C) conductor, (E) embolus, (L) epigynal lip, (M) median apophysis, (N) epigynal notch, (PI) posterior median plate, (PM) paramedian apophysis, (S) scape, $(T)$ tegulum. Scale bars: $11-15=300 \mu \mathrm{m}, 16=200 \mu \mathrm{m}$.

metatarsus 1.02; tarsus 0.55 . Second patella and tibia 1.43; third 0.89 ; fourth 1.5. Epigynum pale, with spermathecae visible through transparent anterior integument. Notch large, scape short (Figs 9 and 15). Posterior plate transparent, through which spermathecae can be seen as two round dark spots (Fig. 10).

Other material examined. BRAzIL, Rio de Janeiro: Maricá, Restinga do Maricá (-22.9605561, -42.842222), 16-19.X.2009, 1 female (UFMG 7150); 6-8.VII.2010, 1 male, 1 female (UFMG 7162); Espírito Santo: São Mateus, Barra Nova (-18.958889, -39.74), 23-27.IX.2009, 1 male (UFMG 7089); Bahia: Mata de São João, Praia do Forte (-12.569444, -38.001944), 5-8.VIII.2010, 6 males (UFMG 7133); Trancoso, Praia de Itaquena (-16.655833, 39.099722), 29-31.VII.2010, male and 11 females (UFMG 7140); Salvador, Parque das Dunas (-12.919167, -38.321667), 79.IX.2009, 1 female (UFMG 7176); Santa Catarina: Florianópolis, Dunas da Joaquina (-27.608056, -48.455), 27-30.VI.2010, 2 females (UFMG 7118), all collected by T. Gonçalves-Souza.

Variation. Males $(\mathrm{N}=4)$ : carapace length, 1.63-1.8; females $(\mathrm{N}=24)$ : carapace length, 1.5-2.1. Some specimens have coxae and trochanters darker; lateral elevations and black spots of abdomen absent in some females, which can have two lateral, wavy black lines on the dorsum of the abdomen.
Natural History. All the specimens were collected in shrubby vegetation in areas of restinga, on plants of five families: Anarcadiaceae, Arecaceae (Allagoptera sp.), Burseraceae (Protium sp.), Sapindaceae (Matayba discolor) and Sapotaceae.

Distribution. Known from restinga areas of Brazil, from the state of Bahia, Espírito Santo, Rio de Janeiro and Santa Catarina (Fig. 17).

Etymology. The specific epithet is a noun in honor on the senior author's father, Antônio Santos Pereira (nicknamed Toninho).

\section{ACKNOWLEDGEMENTS}

We are grateful to Thiago Gonçalves-Souza for collecting the specimens described in this study, to Viviane S. Costa for sorting and organizing all the material in the UFMG collection and Barbara T. Faleiro for help preparing samples for SEM. We also acknowledge the staff of the Centro de Microscopia, UFMG for taking the SEM images. Gracielle F. Braga-Pereira was financially supported by a fellowship from Pronoturno/PROGRAD/ UFMG and Adalberto J. Santos were supported by CNPq (Processes 472976/2008-7 and 300498/2009-8), FAPEMIG (PPM- 


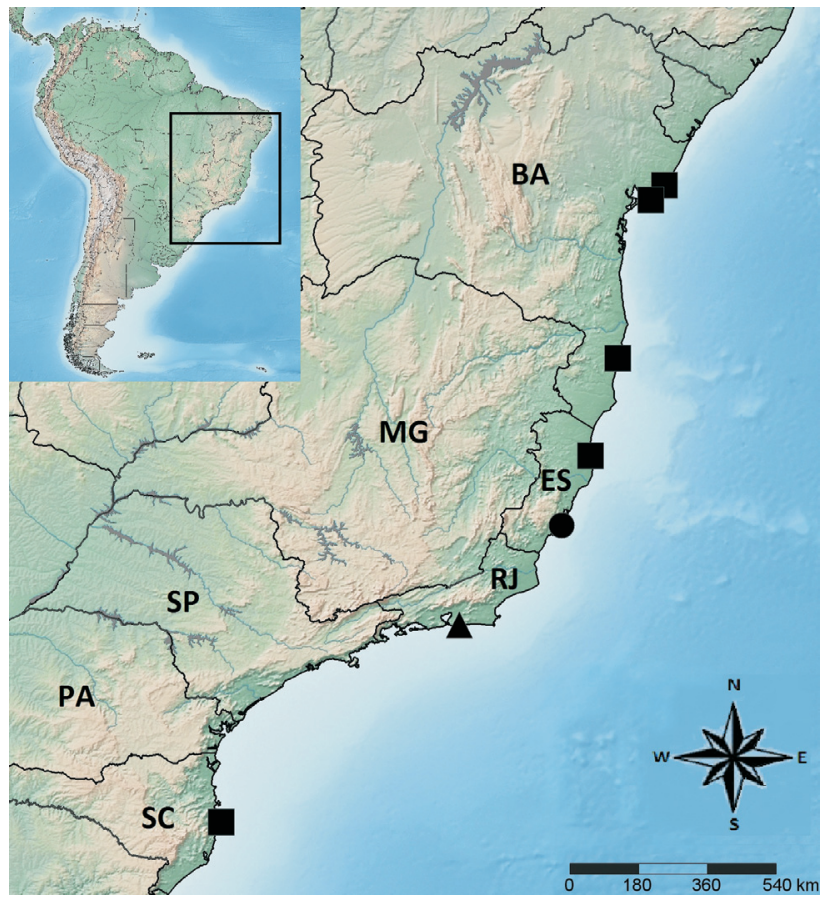

Figure 17. Geographic distribution records of Alpaida toninho sp. nov. and A.teresinha sp. nov. in the Brazilian coast. (square) $A$. toninho, (circle) A. teresinha, (triangle) both species.

00553-11) and Instituto Nacional de Ciência e Tecnologia dos Hymenoptera Parasitóides da Região Sudeste Brasileira. (http:/ /www.hympar.ufscar.br/).

\section{LITERATURE CITED}

Abrahim, N. \& A.B. Bonaldo. 2008. A new species of Alpaida (Araneae, Araneidae) from Caxiuanã National Forest, Oriental Amazonia, Brazil. Iheringia, Série Zoologia 98: 397-399.

Buckup, E.H. \& A.C. Meyer. 1993. Sobre o macho de Alpaida scriba (Araneae, Araneidae). Revista Brasileira de Entomologia 37: 353-354.
Cerqueira, R. 2000. Biogeografia das Restingas, p. 65-75. In: F.A. Esteves \& L.D. LACERDA (Eds). Ecologia de Restingas e Lagoas Costeiras. Macaé, NUPEM/UFRJ.

Framenau, V. W.; N. ScharfF \& H.W. Levi. 2009. Not from "down under": new synonymies and combinations for orb-weaving spiders (Araneae: Araneidae) erroneously reported from Australia. Zootaxa 2073: 22-30.

Levi, H.W. 1988. The Neotropical orb-weaving spiders of the genus Alpaida (Araneae: Araneidae). Bulletin of the Museum of Comparative Zoology, Harvard University 151: 365487.

Levi, H.W. 1992. Spiders of the orb-weaver genus Parawixia in America (Araneae: Araneidae). Bulletin of the Museum of Comparative Zoology, Harvard University 153: 1-46.

Levi, H.W. 1993. American Neoscona and corrections to previous revisions of Neotropical orb-weavers (Araneae: Araneidae). Psyche 99: 221-239.

Levi, H.W. 1999. The neotropical and Mexican orb weavers of the genera Cyclosa and Allocyclosa (Araneae, Araneidae). Bulletin of the Museum of Comparative Zoology, Harvard University 155: 299-379.

Platnick, N.I. 2012. The world spider catalog, version 13.0. American Museum of Natural History, available online at: http://research.amnh.org/entomology/spiders/catalog/ index.html [Accessed: 30.IX.2012].

Rodrigues, E.N.L. \& M.S. MendonçA JR. 2011. Araneid orb-weavers (Araneae, Araneidae) associated with riparian forests in southern Brazil: a new species, complementary descriptions and new records. Zootaxa 2759: 60-68.

SAnTos, K.P. \& Santos, A.J. 2010. Two new species of the orbweaving spider genus Alpaida from Brazil (Araneae: Araneidae). Zootaxa 2336: 61-66.

Submitted: 30.IV.2012; Accepted: 11.X.2012.

Editorial responsibility: Antonio D. Brescovit 